\title{
The Impact of Storms on Legionella pneumophila in Cooling Tower Water, Implications for Human Health
}

\author{
Robin L. Brigmon*, Charles E. Turick, Anna S. Knox and Courtney E. Burckhalter \\ Savannah River National Laboratory, Environmental Science and Biotechnology Group, Aiken, SC, United States
}

At the U.S. Department of Energy's Savannah River Site (SRS) in Aiken, SC, cooling tower water is routinely monitored for Legionella pneumophila concentrations using a direct fluorescent antibody (DFA) technique. Historically, 25-30 operating SRS cooling towers have varying concentrations of Legionella in all seasons of the year, with patterns that are unpredictable. Legionellosis, or Legionnaires' disease (LD), is a pneumonia caused by Legionella bacteria that thrive both in man-made water distribution systems and natural surface waters including lakes, streams, and wet soil. Legionnaires' disease is typically contracted by inhaling $L$. pneumophila, most often in aerosolized mists that contain the bacteria. At the SRS, L. pneumophila is typically found in cooling towers ranging from non-detectable up to $10^{8} \mathrm{cells} / \mathrm{L}$ in cooling tower water systems. Extreme weather conditions contributed to elevations in $L$. pneumophila to $10^{7}-10^{8}$ cells $/ L$ in SRS cooling tower water systems in July-August 2017. L. pneumophila concentrations in Cooling Tower 785-A/2A located in SRS A-Area, stayed in the $10^{8} \mathrm{cells} / \mathrm{L}$ range despite biocide addition. During this time, other SRS cooling towers did not demonstrate this $L$. pneumophila increase. No significant difference was observed in the mean $L$. pneumophila mean concentrations for the towers $(p<0.05)$. There was a significant variance observed in the 285-2A/A Tower $L$. pneumophila results $(p<0.05)$. Looking to see if we could find "effects" led to model development by analyzing 13 months of water chemistry and microbial data for the main factors influencing the $L$. pneumophila concentrations in five cooling towers for this year. It indicated chlorine and dissolved oxygen had a significant impact $(0<0.0002)$ on cooling tower 785A/2A. Thus, while the variation in the log count data for the A-area tower is statistically greater than that of the other four towers, the average of the log count data for the A-Area tower was in line with that of the other towers. It was also observed that the location of 785A/2A and basin resulted in more debris entering the system during storm events. Our results suggest that future analyses should evaluate the impact of environmental conditions and cooling tower design on $L$. pneumophila water concentrations and human health.

Keywords: Legionella pneumophila, cooling tower, weather, biocide, water chemistry 


\section{INTRODUCTION}

Legionella pneumophila, the cause of Legionnaires' disease (LD), is a Gram-negative bacterium ubiquitous in man-made and natural aquatic environments, where it survives in biofilms (Wery et al., 2008). Legionellosis, or Legionnaires' disease, is a pneumonia caused by Legionella bacteria that thrive both in man-made water distribution systems and natural surface waters including lakes, streams, and wet soil (Fliermans, 1985). Legionnaires' disease is typically contracted by inhaling Legionella bacteria, most often in aerosolized mists that contain the bacteria (Ishimatsu et al., 2001). Pontiac fever is generally a nonfatal respiratory disease caused by various species of Legionella that has resulted in outbreaks of influenza-like diseases (Ward et al., 2010).

There are currently over 60 known Legionella species and 71 serogroups of $L$. pneumophila, with many of these serogroups implicated in human disease (Me'rault et al., 2011; Katsiaflaka et al., 2016; Miyashita et al., 2020). L. pneumophila serogroup 1 is most frequently implicated in disease and is the strain most commonly found in the natural environment (Marston et al., 1994; Lawrence et al., 1999; Lettinga et al., 2002). However, other Legionella types have also been implicated in disease, most often Legionella pneumophila serogroups 4 and 6, as well as other serogroups (Buchbinder et al., 2002; Fields et al., 2002; Paranjape et al., 2020), and coinfections with several Legionella species due to immunodeficiencies (Matsui et al., 2010).

Most world-wide LD outbreaks have been associated with cooling towers, since Legionella can persist in these systems and release viable bacteria in the aerosolized effluents (Berendt, 1980; Sanchez et al., 2008). Under certain conditions, including low disinfectant concentrations, high organic levels, and warm temperatures, Legionella can readily propagate in these structures (Kusnetsov et al., 1997). In recent years, it is likely that more cases of LD have been reported worldwide due to increased awareness of Legionella in the environment and workplace, more accurate and accessible clinical testing, technological advances in microbial source tracking, and increased monitoring of water treatment systems (Fields et al., 2002). Current clinical methods for detecting Legionella antigen in the urine of infected patients targets primarily Serogroup 1 (Bibb et al., 1984; AgueroRosenfeld and Edelstein, 1988). The Legionella urinary antigen test has had a major impact on epidemiological trends in outbreaks of Legionellosis, as it circumvents the difficulty of clinical isolation and identification (Alvarez et al., 2009). It is possible that some species have not yet been associated with human disease because they occur so rarely in nature; therefore, all Legionella strains should be considered potentially pathogenic (Atlas, 1999). Since Legionella species are fastidious to isolate and culture, identification of new species/serogroups is exceedingly difficult (Hussong et al., 1987; Bentham, 2000).

The detection or presence of Legionella in water or on a fixture or device is not enough to cause disease (Kim et al., 2002). For disease to develop, individuals must inhale enough virulent organisms to overwhelm their natural resistance (Shelton et al., 2000). A common source of Legionella is from cooling towers, commonly used for cooling water, with utility ranging from industrial processes to residential buildings. Towers with excess organics including pollen, soil, and other detritus; and other suspended solids, such as algae, and other microorganisms can shield Legionella from biocides and provide an environment conducive to bacterial growth (Pinel et al., 2020). Legionella bacteria must be virulent and, in enough concentrations, to cause disease (Marston et al., 1994). In most cases, the water source must be aerosolized and distributed so the human host can inhale Legionella through mists (Nguyen et al., 2006). For disease to occur, Legionella must be inhaled or aspirated deeply into the lungs to the alveoli by the potential host(s), and the host must be physiologically unable to stop the infection (Dalebroux et al., 2009). The infectious dose of Legionella for humans has not been determined, but the larger the dose, the more likely an infection will occur (Emmerson, 2001). Length of exposure can also be a factor and the risk of infection is greater when the dose of Legionella-containing water is in direct, close contact with the susceptible population, as is the case with humidifiers/foggers or maintenance work on water systems (Berendt, 1980; Bentham and Broadbent, 1993). Meteorological conditions conducive to low-level inversion and high humidity have been linked to cooling tower LD outbreaks and/or to Legionella stability in aerosols (Ishimatsu et al., 2001; Dunn et al., 2013). Cooling towers near workers or the general population are of concern because of the potential exposure from massive amounts of aerosolized mists generated (Brown et al., 1999).

In epidemiological studies of Legionella disease outbreaks, the infection rates have been demonstrated to be greater for those who are hospitalized, older, smokers, heavy drinkers, disease compromised, or on immunosuppressive therapy, and these factors are often listed as risk factors for LD. Other factors that may contribute to higher LD risk are diabetes, chronic bronchitis, cancer, AIDS, and end-stage renal disease. It is theorized that a lower dose of Legionella may cause infection in individuals with one or more of these conditions (Fields et al., 2002).

Occupational sources of Legionella include building, industrial, and other man-made water systems. These manufactured water systems can include cooling towers, scrubbers, evaporative condensers, humidifiers, water heaters, holding tanks, pipes, shower heads, faucets, nebulizers, misters, and whirlpool baths (Cooper et al., 2004). Groundwater sources for municipal use and other water distribution systems have been found to contain Legionella spp. (Costa et al., 2005). Legionella bacteria survive in low numbers in routinely treated domestic water and can be carried into buildings through domestic treated water. The bacteria can colonize and be transmitted from plumbing fixtures, including shower heads and hot-water taps (Bollin et al., 1985; Allegra et al., 2020). Investigations of nosocomial infections in hospitals have often found the cause to be the potable water supply. Cooling towers and industrial water systems have been shown to be colonized with Legionella through the make-up water.

Cooling towers have been the principal agents for disseminating Legionella with resulting disease and, in some cases, deaths (Alvarez et al., 2009). Most cases of Legionellosis occur as sporadic cases, not epidemics. The risk exists not only for people in the buildings and structures where the cooling towers are located, but also to passers-by and people some distance from the tower who might be exposed to cooling tower 
mists. In a 1978 outbreak, people were infected both inside and outside a hospital near the source cooling tower (Dondero et al., 1980). In that case, a correlation was demonstrated between LD cases and areas of the hospital that received ventilating air from intakes close to the cooling tower containing L. pneumophila.

The concentration of Legionella that has been linked to the causation of disease associated outbreaks is as low as 2.3 Colony Forming Units (CFU), depending on the source and conditions (Whiley et al., 2014). For example, an outbreak in Sweden was linked to a Legionella concentration of $1.2 \times 10^{9}$ cells $/ \mathrm{L}$ in cooling tower water (Ulleryd et al., 2012). "Health-threatening" levels of Legionella have been determined to be $1.0 \times 10^{6}$ cells/ $\mathrm{L}$ culturable populations, while "high Legionella concentration" has been defined as $1.0 \times 10^{7}$ cells/L, and "high level of concern" has been defined as ranges from $10^{8}$ to $10^{9}$ cells/L concentrations (Atlas, 1999).

A variety of biocides used alone or in combination are used for Legionella control, including chlorine $(\mathrm{Cl})$, bromine $(\mathrm{Br})$, ozone, and various formulations (Kim et al., 2002; Miller and Koebel, 2005). Effective biocide chemistry encompasses both the primary element in the biocide $(\mathrm{Cl}, \mathrm{Br}$, etc.) and maintenance of water quality (e.g., conductivity). Effective biocide use demands maintenance of prescribed concentrations and the adjustment of concentrations to changing demand associated with elevated temperatures or heavy organic concentrations. Temperature can impact L. pneumophila growth in cooling tower biofilms and circulating water as well as the associated microbial and eukaryotic communities (Paniagua et al., 2020). Maintenance issues, including scale and dust build up, can influence biocide activity, and adjusting biocide concentration to account for these influences may enhance Legionella control. Corrosion or deterioration of water tower construction materials can lead to increased metal concentrations in circulating water. Biocides can also cause corrosion in water distribution as well (Marchesi et al., 2016.) The results of microbiological studies indicate that while elevated concentrations of certain metals are toxic, lower levels of iron, zinc, and potassium can enhance L. pneumophila growth (Zahran et al., 2017). While ozone has been shown to be an effective biocide when there are no organics, its use offers no residual activity and control. The use of specific biocides depends on the needs of the tower, the environmental regulations on effluents, specific design of the cooling tower, need for biofilm penetration, and cost efficiency (Lau and Ashbolt, 2009). Material in water distribution systems is also a consideration in selection of chemical treatment, since some biocides can be more corrosive than others (Marchesi et al., 2016). The aim of this study is to understand the impact of water chemistry and seasonality on L. pneumophila in cooling towers operating under a variety of conditions in a temperate location. A similar approach may be applied to other cooling towers in different geographic locations.

\section{MATERIALS AND METHODS}

At the U.S. Department of Energy's Savannah River Site (SRS) in Aiken, SC, cooling tower water is routinely monitored for
L. pneumophila concentrations (serogroups 1, 2, 4, and 6) on a monthly or quarterly basis using a direct fluorescent antibody (DFA) technique. Historically, the 30 operating SRS cooling towers have had varying concentrations of Legionella in all seasons of the year, with patterns that are unpredictable. The cooling towers are of varying age, water treatment system, construction, size, water supply, and geographical distribution over the 320 square miles of the SRS. A stoplight system based on cooling tower water L. pneumophila concentrations has been developed to help operators control microbial growth. For this system, "green" is from 0 to $10^{6}$ cells/L, "yellow" is $10^{6}-10^{7}$ cells/L, and "red" is $10^{7}$ cells/L or greater. Red requires extra vigilance by management and biocide shocking procedures to bring L. pneumophila concentrations down. Extreme weather conditions contributed to elevations in L. pneumophila up to $10^{7}-10^{8}$ cells/L in the SRS cooling tower water systems. The location of the five cooling towers used in this work relative to the SRS are shown in Figure 1.

\section{Water Samples}

Sterilized $500 \mathrm{~mL}$ polycarbonate sample bottles are used to sample these individual cooling tower waters. Water samples are collected directly from tower basins and split into two $500 \mathrm{~mL}$ samples. One sample is placed in a cooler and the other is used for on-site analysis for physical and chemical parameters. A calibrated Yellow Springs Instrument (YSI) MPS 552 multiparameter meter (YSI, Yellow Springs, Ohio) is used to measure temperature $\left({ }^{\circ} \mathrm{C}\right)$, conductivity [Siemens per meter $(\mathrm{S} / \mathrm{m})$ in SI and millimhos per centimeter $(\mathrm{mmho} / \mathrm{cm})], \mathrm{pH}$, and dissolved oxygen (DO) (\%) on site after collection. Palintest 1000 test kits are used to measure total $\mathrm{Br}$ and/or free $\mathrm{Cl}$ (Palintest House, Kingsway, United Kingdom).

\section{Microbiological Analysis}

Legionella pneumophila is concentrated in the cooling tower water samples $(500 \mathrm{~mL})$ in the laboratory by filtering water samples through a filtration membrane (47-mm-diameter, 0.4$\mu \mathrm{m}$ pore size filters-Whatman Nucleopore; GE Healthcare Life Sciences, Piscataway, NJ, United States) prior to DFA testing. Each filter set was aseptically cut and placed into a $15-\mathrm{mL}$ conical tube (Thermo Fisher Scientific), $1 \mathrm{ml}$ of $0.2-\mu \mathrm{m}$-filter sterilized FA Buffer (Difco; Thermo Fisher Scientific, Detroit, MI, United States) was added, and tubes were vortexed for 4 min. Eight-well glass slides (Carlson Scientific, Peotone, IL, United States) pretreated at $90^{\circ} \mathrm{C}$ were rinsed with $70 \%$ ethanol prior to sample deposition. Inactivated L. pneumophila serogroups 1, 2, 4, and 6 cells were acquired from Monoclonal Technologies, Inc. (Alpharetta, GA, United States) and served as positive controls for the DFA. Serratia marcescens (ATCC 13880) served as the DFA negative control well as a water control to test for non-specific binding. Sample replicates $(10 \mu \mathrm{L})$ were added to four wells of a prepared slide and heat fixed at $80-90^{\circ} \mathrm{C}$ for $10-$ $15 \mathrm{~min}$. Slides were then placed into a $25^{\circ} \mathrm{C}$ humidified chamber for $20 \mathrm{~min}$. Each heat fixed sample was separately stained with $20 \mu \mathrm{L}$ of antibody fluorescein isothio-cyanate (FITC)labeled monoclonal antibodies for L. pneumophila serogroups 1 , 


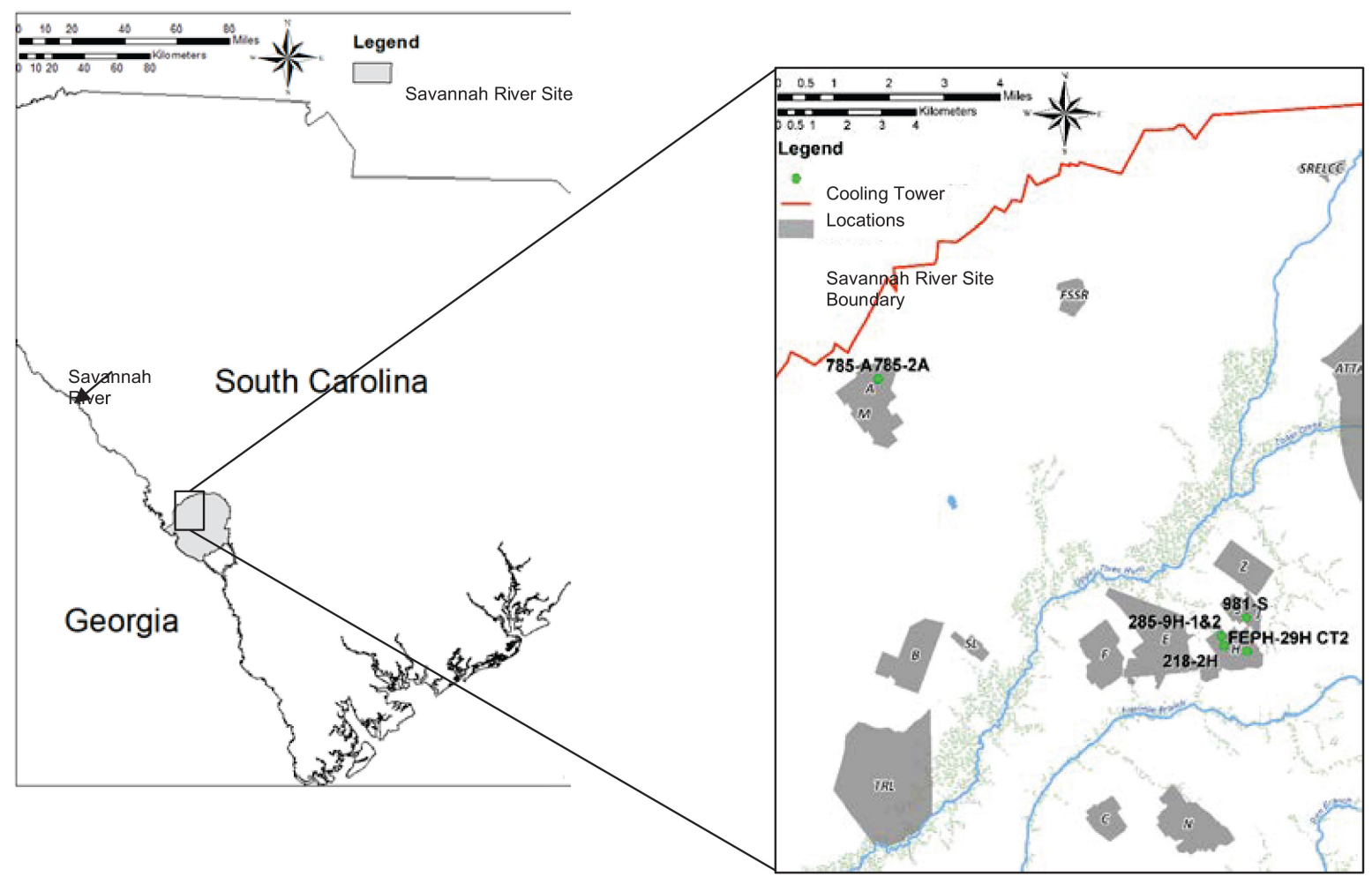

FIGURE 1 | Geographical distribution of cooling towers 785-A/785-2A, 285-9H-1\&2, 218-2H, FEPH-29H CT2, and 981-S relative to the Savannah River Site in South Carolina.

2, 4, and 6 (Monoclonal Technologies, Inc.). These serogroups were selected as they are most commonly linked with disease outbreaks, especially serogroup 1 (Shelton et al., 1994; Fields et al., 2002). Slides were rinsed with DI water and stored overnight in FA buffer at $25^{\circ} \mathrm{C}$. Slides were then rinsed with $5 \%$ sodium pyrophosphate (Difco; Thermo Fisher Scientific) buffer and allowed to dry in the dark at $25^{\circ} \mathrm{C}$. Slides were then examined and DFA labeled L. pneumophila cells counted with fluorescent microscopy (Zeiss Axioscope 2) at $1000 \times$ and concentrations of the species and serotype determined as previously described (Leskinen et al., 2012). The positive and negative controls were run with each set of monthly cooling tower samples.

\section{Statistical Analysis}

Comparisons of the L. pneumophila concentrations (cells/L) for a 13-month period between 2016 and 2017 with physical, chemical, and environmental parameters were performed with JMP Pro Version 11.2.1 SAS Institute Inc., Cary, NC, 2014. These parameters included cooling water $\mathrm{pH}$, conductivity $(\mathrm{mS} / \mathrm{cm})$, temperature (water and air) $\left({ }^{\circ} \mathrm{C}\right), \mathrm{DO}(\%), \mathrm{Cl}, \mathrm{Br}$, turbidity (NTU), wind $(\mathrm{m} / \mathrm{s})$, and rain (in). Five SRS cooling towers that were sampled monthly during this time period were selected for analysis including 218-2H, 285-9H-1\&2, FEPH-29H-CT3, 981$\mathrm{S}$, and $785 \mathrm{~A} / 2 \mathrm{~A}$. Cooling tower $785 \mathrm{~A} / 2 \mathrm{~A}$ was sampled two times monthly when $L$. pneumophila concentrations were elevated for a total of 15 replicates.

\section{RESULTS}

Mean monthly Savannah River Site temperature $\left({ }^{\circ} \mathrm{C}\right)$, windspeed (m/s), and rainfall total (in.) for 4/1/2017-4/15/2018 is shown in Figures 2A-C, respectively. Note the peak rainfall and wind speeds for August and September 2017, when Hurricanes Harvey and Irma came through the Southeastern United States. Temperature was slightly down during this time period due to the storm conditions (wind, rain, clouds). While the Savannah River Site was not directly hit by these hurricanes, the wind and rain had a major impact. On September 11, 2017, wind speed peaked at $9.51 \mathrm{~m} / \mathrm{s}$ (Figure 1B), and rainfall was 5.30 inches in one day (Figure 1C). In a nationwide study, a precipitation threshold above $750 \mathrm{~mm}$ (2.95 inches) was found to contribute significantly to elevated legionellosis activity (Han, 2019).

Comparing the data across the cooling towers for the L. pneumophila concentrations (expressed in natural logs, i.e., $\ln [\mathrm{L} A($ cells/L) $]$ ) yielded the results shown in Table 1 . Included in Table 1 are the standard deviations (std devs) in each cooling tower, as well as the results for Levene's and Welch's statistical tests. Levene's test for variance equality for the log count data for L. pneumophila across the cooling towers indicates that the variances are statistically different at the 5\% significance level, with $785 \mathrm{~A} / 2 \mathrm{~A}$ having the largest variance. Figure $\mathbf{3 A}$ shows the analysis of $\ln$ (Cell count) by cooling tower for the year, demonstrating the variance in A-Area Tower. 


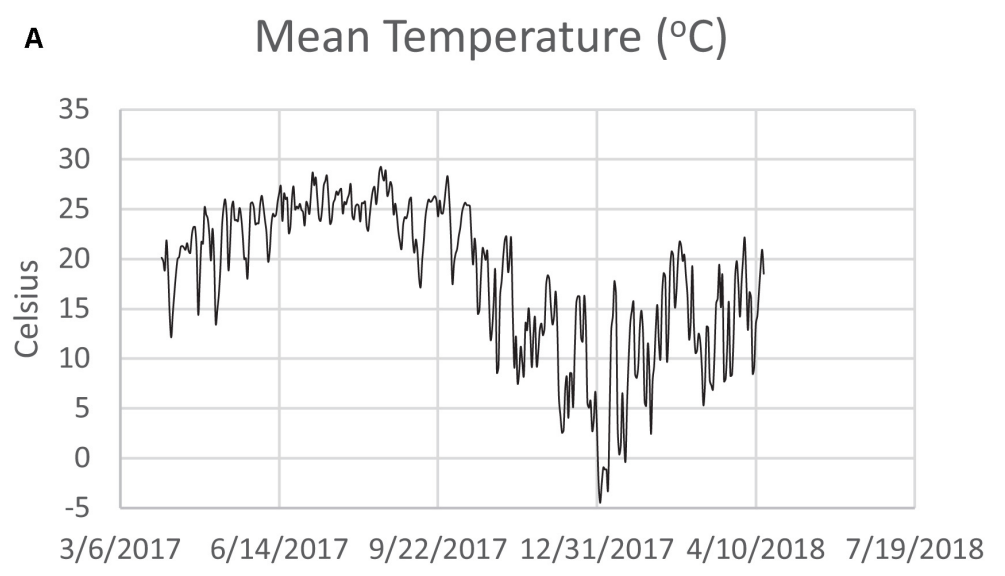

B

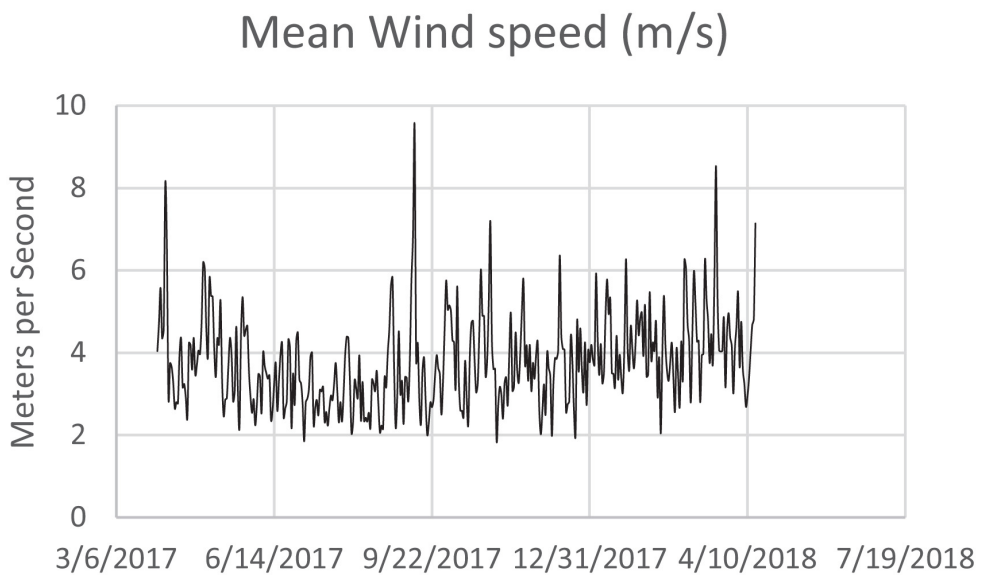

C

Rainfall Totals (in.)

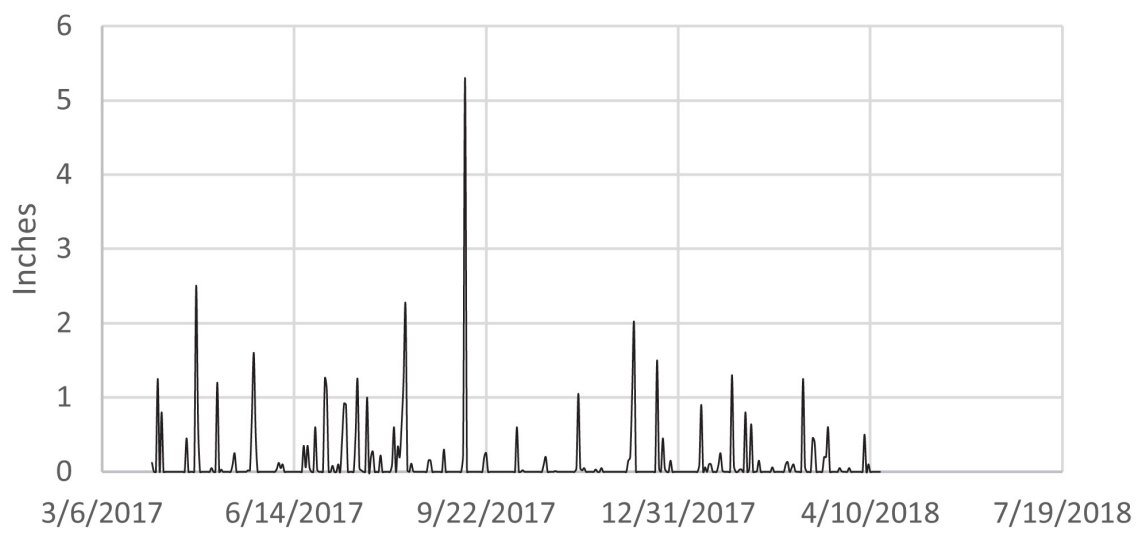

FIGURE 2 | (A) Mean monthly Savannah River Site temperature $\left({ }^{\circ} \mathrm{C}\right)$ for 3/6/2017-7/19/2018. (B) Mean monthly Savannah River Site wind speed (m/s) for 3/6/2017-7/19/2018. (C) Mean monthly Savannah River Site rainfall (in.) for 3/6/2017-7/19/2018. 
TABLE 1 | Cooling tower water Legionella pneumophila concentration comparisons.

\begin{tabular}{|c|c|c|c|c|c|}
\hline Level & Count & Std dev & \multicolumn{2}{|c|}{ MeanAbsDif to Mean } & MeanAbsDif to Median \\
\hline $218-2 \mathrm{H}$ & 12 & 1.543120 & \multicolumn{2}{|c|}{1.345350} & 1.304034 \\
\hline $285-9 \mathrm{H}-1 \& 2$ & 12 & 1.463006 & \multicolumn{2}{|c|}{1.044911} & 1.038666 \\
\hline $785 \mathrm{~A} / 2 \mathrm{~A}$ & 15 & 2.501282 & \multicolumn{2}{|c|}{2.064472} & 2.044219 \\
\hline $981-S$ & 12 & 1.340178 & \multicolumn{2}{|c|}{0.992456} & 0.985878 \\
\hline FEPH-29H-CT3 & 14 & 1.521459 & \multicolumn{2}{|c|}{1.125929} & 1.098230 \\
\hline Test & & & DFNum & DFDen & Prob $>\boldsymbol{F}$ \\
\hline O’Brien[.5] & & & 4 & 60 & 0.0160 \\
\hline Brown-Forsythe & & & 4 & 60 & 0.0560 \\
\hline Levene & & & 4 & 60 & 0.0334 \\
\hline Bartlett & & & 4 & . & 0.1314 \\
\hline \multicolumn{6}{|l|}{ Welch's Test } \\
\hline \multicolumn{6}{|c|}{ Welch Anova testing Means Equal, allowing Std Devs Not Equal } \\
\hline F ratio & & & DFNum & DFDen & Prob $>\boldsymbol{F}$ \\
\hline 0.7932 & & & 4 & 29.83 & 0.5390 \\
\hline
\end{tabular}

Figure 3B provides a plot of the variances, showing the higher deviation in the A-Area Tower. The results from Welch's test for the means of the cooling tower L. pneumophila monthly data being equal indicates that there is no statistically significant difference (at the 5\% significance level) in the means of these data (Table 1). Thus, while the variation in the log count data for the $\mathrm{A}$-area tower is statistically greater than that of the other towers, the average of the log count data for the A-area tower is in line with that of the other towers.

\section{Tests That the Variances Are Equal}

A statistical model of the $\ln [\mathrm{L} A$ (cells/L)] values for the A-Area Tower was explored. The results of this effort are in Table 2. The model for $\ln [\mathrm{L} A$ (cells/L)] as a linear function of DO and Free $\mathrm{Cl}$ (as measured in A Tower) explained $86.4 \%$ of the variation seen in these log data with no indication of a lack of fit for the model. Both parameter estimates are negative, which implies that as $\mathrm{DO}$ and/or Free $\mathrm{Cl}$ increases, the model predicts that the L. pneumophila concentrations are expected to decrease. The contour plot of model predictions shows this graphically in Figure 4. It was found that Br cooling tower water concentrations, generally $50 \%$ lower than $\mathrm{Cl}$, were not significant regarding L. pneumophila concentrations. Similarly, the cooling tower water $\mathrm{pH}$ averaged around 9.0, but was also found to be not significant with respect to L. pneumophila concentrations.

Environmental conditions can impact L. pneumophila control in cooling towers, as observed with extreme 2018 summer weather in data presented here. Cooling tower 785$\mathrm{A} / 2 \mathrm{~A}$ concentrations went from averaging $10^{5}-10^{6}$ cell/L to $10^{7}-10^{8}$ cell/L after Hurricanes-Harvey-and-Irma-associated extreme weather (Figure 5). The increase in L. pneumophila concentrations seemed to lag just behind the heavy rain, indicating a cumulative effect (Figure 5). Despite automated biocide addition, these increases were likely due to impact of windblown debris into the cooling tower and basin with excessive rain. The towers are typically cleaned once yearly during the winter months, so regular maintenance was not a factor in this case. This increase of debris observed in the cooling tower basin may have contributed to the decrease in DO associated with the increase in L. pneumophila concentrations (Figure 4). It has been shown that monitoring Legionella aerosols around contaminated cooling towers during fog conditions may be a valuable contribution to the risk assessment and prevention of LD outbreaks (Villanueva and Schepanski, 2019). For more efficient monitoring for Legionella detection, new experimental predictive methods of contamination could be implemented alongside the classical microbiological methods, such as Geostatistics, which could be applied just in the case of aerosol distribution from the cooling towers (Laganà et al., 2015; De Giglio et al., 2019; Allegra et al., 2020). An experimental setup provided data that demonstrated Legionella risk exposure and associated dose-response of a Legionella infection from aerosols generated by nebulizers to lung deposition (Allegra et al., 2020).

\section{DISCUSSION}

Contamination of man-made water distribution systems including water supplies with Legionella is an established cause of legionellosis. Water sources of large buildings, such as hospital distribution systems and cooling towers, are often contaminated with Legionella and therefore represent a potential danger to patients, occupants, and workers (Brown et al., 1999; Wellinghausen et al., 2001). Efficient water monitoring and detection of elevated L. pneumophila concentrations is essential to prevent cases from occurring (Buchbinder et al., 2002; Chang et al., 2009; Carducci et al., 2010). While L. pneumophila is the main causative agent of legionellosis, detection and differentiation can be difficult due to problems with nonviable cultures (Edagawa et al., 2009). L. pneumophila-containing aerosols from anthropogenic devices, including cooling towers, are known to be a problem with a direct impact on human health (Allegra et al., 2020), Because legionellae can be difficult to culture 


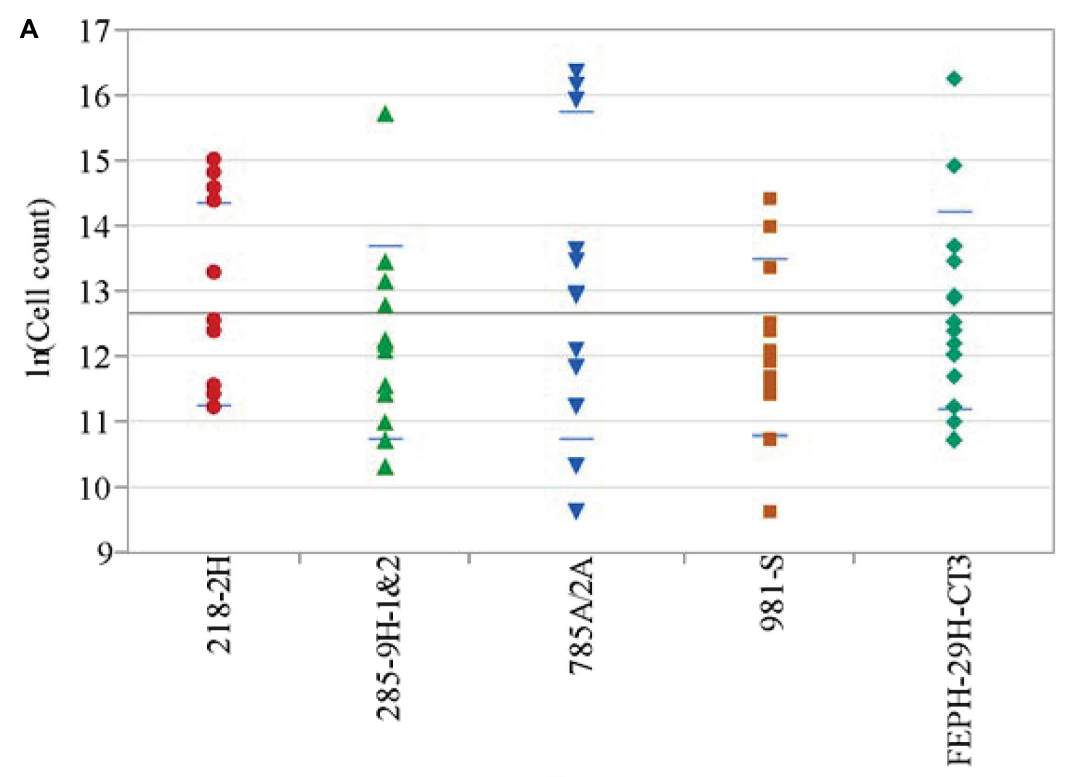

Cooling Tower

B

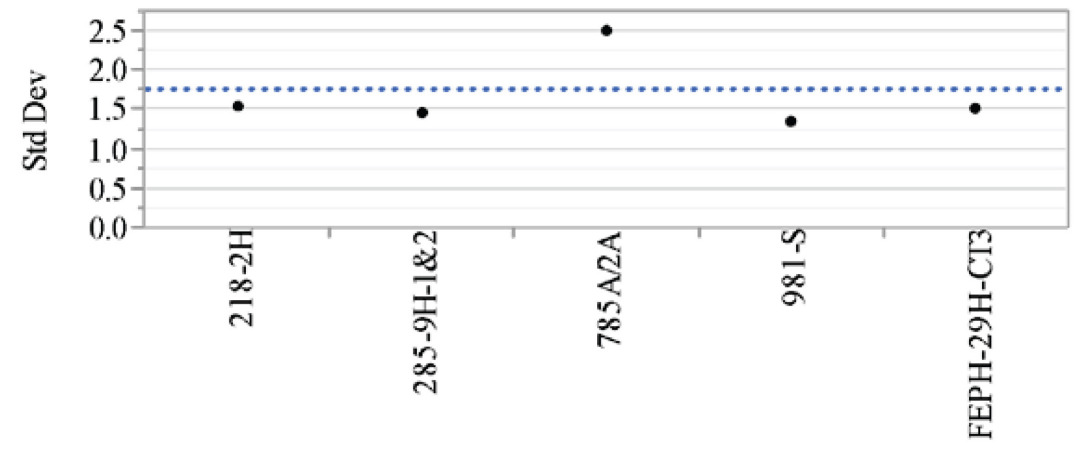

Cooling Tower

FIGURE 3 | (A) Analysis of Legionella pneumophila concentrations In(Cell count) by cooling tower. (B) Variance of Legionella pneumophila concentrations In (cell count) by cooling tower.

and cells may be damaged due to biocides as well as the desire for direct identification, immunofluorescence is often preferred for identification and quantification (Bibb et al., 1984; Edelstein and Edelstein, 1989). In a previous study at SRS with the same DFA applied here, cooling tower water concentrations of Legionella were determined using a Portable Multi-use Automated Concentration System (PMACS) concentrates micro-organisms from large volumes of water through automated dead-end ultrafiltration and backflushing (Leskinen et al., 2012). The DFA is a rapid test that does require expertise as whole cells are counted to determine concentrations. While live cells can be determined alongside DFA with a counter stain, that was not done here. The sensitivity of DFA has been found to be about $70 \%$ for detection of L. pneumophila serogroup 1 with specificity approaching 99\% (Pierre et al., 2017). The DFA technique has been a standard for our laboratory for determination of
L. pneumophila in cooling towers (Fliermans, 1985). For cooling tower water, the DFA allows rapid analysis for samples with varying complicating factors including high biocides, e.g., $\mathrm{Cl}$ and other chemicals including anticorrosion agents. DFA results from SRNL cooling tower water have been correlated with $\mathrm{qPCR}$ findings in past unreported studies with Clemson University (Tamara McNealy, personal communication).

Legionella pneumophila is known to thrive in certain natural aquatic environments without biocides including rain puddles (Sakamoto et al., 2009). Cl can react with organic matter such as the debris observed in the cooling tower basin and leave behind unwanted compounds such as trihalomethanes (THMs) and haloacetic acid (HAAs), which reduce $\mathrm{Cl}$ effectiveness (Al-Abril et al., 2019). While biocides, in this case $\mathrm{Cl}$, have long been used to control L. pneumophila growth in water distribution systems (Marchesi et al., 2016) the interesting factor here is the 
TABLE 2 | Analysis of variance for Cooling Tower 785-2A dissolved oxygen (DO) and free chlorine (Free Cl) relative to Legionella pneumophila concentrations.

\section{Summary of Fit}

RSquare

R Square Adj

Root Mean Square Error

1106

Mean of Response

Observations (or Sum Wgts)

\section{Analysis of Variance}

\begin{tabular}{|c|c|c|c|c|}
\hline Source & DF & Sum of Squares & Mean Square & F Ratio \\
\hline Model & 2 & 77.754 & 38.877 & 31.804 \\
\hline Error & 10 & 12.224 & 1.222 & Prob $>F$ \\
\hline C. Total & 12 & 89.978 & & $<0.0001^{*}$ \\
\hline \multicolumn{5}{|l|}{ LackOfFit } \\
\hline Lack Of Fit & 8 & 10.5978 & 1.325 & 1.629 \\
\hline Pure Error & 2 & 1.626 & 0.813 & Prob $>F$ \\
\hline
\end{tabular}

\section{Parameter Estimates}

\begin{tabular}{lcccr}
\hline Term & Estimate & Std error & $\boldsymbol{t}$ Ratio & Prob $>|\boldsymbol{t}|$ \\
\hline Intercept & 17.427 & 0.625 & 27.90 & $<0.0001^{*}$ \\
ADO & -0.052 & 0.007 & -7.00 & $-0.0001^{*}$ \\
AFree Cl & -1.039 & 0.181 & -5.75 & $0.0002^{*}$
\end{tabular}

*Significant at the 5\% level.

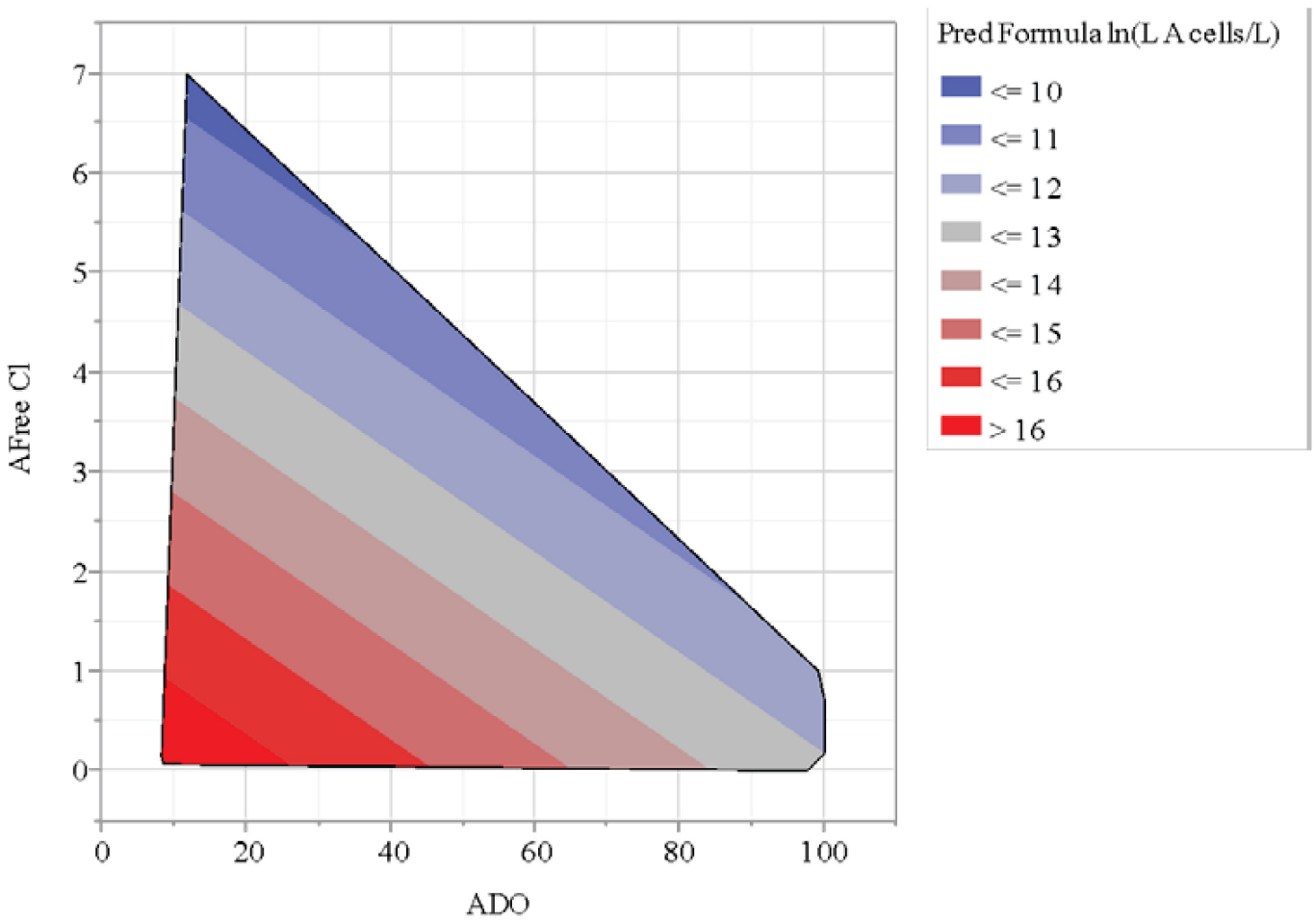

FIGURE 4 | Contour plot of chlorine (Cl) and dissolved oxygen (DO) relationship with L. pneumophila concentrations (cells/L). 


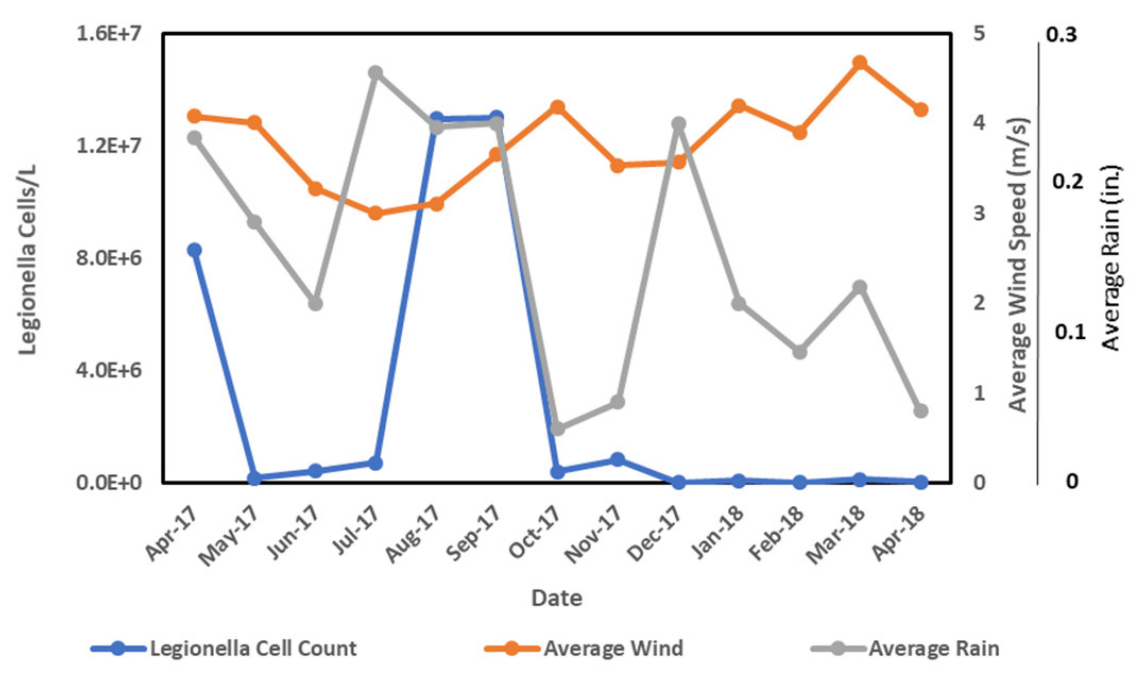

FIGURE 5 | Average wind and rain effects on Legionella concentrations for the 785A/2A cooling tower.

interaction with DO. The correlation of DO and Cl- is of interest as L. pneumophila, a microaerophilic microorganism, has been found to typically thrive in water DO of 6.0-6.7 mg/L (Wadowsky et al., 1985). In that work L. pneumophila did not replicate in tap water which contained less than $2.2 \mathrm{mg}$ of DO per liter. This particular cooling tower, $785 \mathrm{~A} / 2 \mathrm{~A}$, was subjected to rain, wind, and influx of debris into a basin that may have been conducive to biofilm formation. The large basin and build-up of debris set it apart from the other cooling towers evaluated that did not demonstrate elevated L. pneumophila concentrations during this time even through exposed to similar wind and rains from the extreme weather. While $\mathrm{pH}$ is known to impact L. pneumophila viability that prefers a near neutral $\mathrm{pH}$ (Wadowsky et al., 1985), it was not found to be a significant factor in the course of this 13-month study. Cooling tower operators often maintain the circulating water at a higher $\mathrm{pH}$ to limit corrosion.

Management of cooling towers can be a factor, as the presence of stagnant water, lack of maintenance, and/or environmental conditions can cause L. pneumophila buildup (Fliermans, 1985; Bentham, 2000). Interactions of L. pneumophila with amoeba can also complicate detection and eradication (McNealy et al., 2002). Amoebae can be infected with L. pneumophila in cooling towers that can vary greatly metabolically with different aquatic environments (Berk et al., 2006). Acanthamoeba have been found to contain respirable vesicles containing live L. pneumophila cells, indicating a unique survival mechanism for cooling tower environments, and may increase their survivability (Berk et al., 1998).

In this study we applied DFAs to four L. pneumophila known to cause most human disease cases. There are actually a variety of Legionella species that can cause LD (Miyashita et al., 2020). Many of these species due to their biodiversity are difficult to detect, isolate, and culture (Hussong et al., 1987). For this reason, the Legionella urinary antigen test has become the main tool for clinical diagnoses (Bibb et al., 1984). While L. pneumophila serogroup 1 causes from 50 to $80 \%$ of $\mathrm{LD}$, it is estimated that as many as $20-50 \%$ of cases of LD are missed if the urine antigen is the only diagnostic test (Pierre et al., 2017).

Figure 5 demonstrates the impact of the elevated wind, rain, and subsequent increase in L. pneumophila concentrations. While rainfall was observed to be elevated in December, an increase in Legionella was not observed as rainfall was not prolonged as observed earlier in the July, August, and September time frame (Figure 5). Because the cooling tower water samples are taken monthly for L. pneumophila testing, the initial increase may have been earlier than the actual testing date. L. pneumophila outbreaks found to be from cooling tower sources have resulted in increased vigilance maintenance and control of existing cooling systems (Nguyen et al., 2006; Ulleryd et al., 2012). Legionnaires' disease cases often remain largely underdiagnosed with outbreaks not properly determined, due to the pneumonia-like symptoms mimicking other ailments, and lack of testing (Spiegelman et al., 2020). In addition, while many biocides are available for water treatment and Legionella prevention, environmental aspects including other biota (Orrison et al., 1983; McNealy et al., 2002), water chemistry (Kim et al., 2002), and environmental factors can influence its survival and recalcitrance to biocides (Mallison, 1980). In Japan, L. pneumophila was found to be abundant in rainwater puddles, especially during warm weather (Sakamoto et al., 2009). These multiple sources could lead to higher background ambient levels of L. pneumophila due to anthropogenic aerosols generated by construction, traffic, or other activities (Parthuisot et al., 2010). Using the Nationwide Inpatient Sample and U.S. weather data, it has been estimated that the probability of community-acquired pneumonia (CAP) being diagnosed LD increases when weather is warm and humid (Simmering et al., 2017). The results were found to vary by region due to geographic and seasonal differences in humidity and temperature.

Biocides can react with other chemical species, rendering them ineffective. In the 2014-2015 LD outbreak in Flint, Michigan, it was found that an increase in free $\mathrm{Cl}$ demand, with 
increased concentrations of iron and assimilable organic matter from corroded pipes, stimulated legionellae growth and reacted chemically with free $\mathrm{Cl}$, thereby reducing its biocide effectiveness (Zahran et al., 2017).

\section{CONCLUSION}

While no cases of legionellosis were documented in this case at the SRS during this time of extreme weather, conditions including summer weather, high rainfall, increased humidity, and cloudy conditions were conducive for Legionella growth conditions. The factor of temperature and high precipitation have been linked with higher incidences of Legionellosis (Han, 2019). The potential for human exposure from cooling towers at these Legionella concentrations and atmospheric conditions are clear (Villanueva and Schepanski, 2019). A clean-out of the cooling tower basin and repeated biocide applications were required to bring L. pneumophila below $10^{6}$ cells/L -the safe or "green" level -in this cooling tower water. Other SRS towers, including the four in this comparison, were not exposed to as much debris as $785-\mathrm{A} / 2 \mathrm{~A}$. While they did not demonstrate the L. pneumophila increase despite the extra precipitation, and varied from not detected (ND) range up to $10^{6}$ cells/L as measured by DFA, the average for the year was the same; but significant variability in $785-\mathrm{A} / 2 \mathrm{~A}$ was caused by the weather factors. While [Br] generally follows [Cl] in our cooling tower water monitoring, $[\mathrm{Cl}]$ alone was correlated with the L. pneumophila indicating water chemistry has to be closely followed in extreme conditions. Thus, the findings of this work emphasize the significance of understanding the resilience and ecology of L. pneumophila in cooling tower water in terms of public health.

Uncertainties related to Legionella risk assessment in cooling towers due to variations in operation, environmental conditions, and management have been discussed in this work. This is in part due to the fact source tracking can be difficult for legionellosis (Addiss et al., 1989). Biofilm development in cooling towers can also make control and detection of L. pneumophila in circulating water difficult (Declerck, 2010). The effectiveness of regulatory, monitoring, and health issues related to Legionella risk has been reviewed by Whiley et al. (2014). Recent findings of inhibitive solar effects of UV radiation and sunshine hours

\section{REFERENCES}

Addiss, D. G., Davis, J. P., LaVenture, M., Wand, P. J., Hutchinson, M. A., and McKinney, R. M. (1989). Community-acquired Legionnaires' disease associated with a cooling tower: evidence for longer-distance transport of Legionella pneumophila. Am. J. Epidemiol. 130, 557-568. doi: 10.1093/oxfordjournals.aje. a115370

Aguero-Rosenfeld, M. E., and Edelstein, P. H. (1988). Retrospective evaluation of the Du Pont radioimmunoassay kit for detection of Legionella pneumophila serogroup 1 antigenuria in humans. J. Clin. Microbiol. 26, 1775-1778. doi: 10.1128/jcm.26.9.1775-1778.1988

Al-Abri1, M., Al-Ghafri, B., Bora, T., Dobretsov, S., Dutta, J., Castelletto, S., et al. (2019). Chlorination disadvantages and alternative routes for biofouling control on legionellosis (Han, 2019) may help explain the increased level in L. pneumophila observed here under stormy and cloudy conditions.

In summary, we have shown that despite an operating biocide system, L. pneumophila concentrations were elevated in a cooling tower as a function of extreme weather conditions, including rain and wind bringing in debris. L. pneumophila concentrations in Cooling Tower 785-A/2A stayed in the $10^{8}$ cells/L range despite biocide addition due to environmental conditions. The cooling tower remained in the red zone containing higher cells/L than the permissible limit. Incorporation of free $\mathrm{Cl}$ and $\mathrm{DO}$ decreases the number of L. pneumophila in the cooling towers when possible. We have also shown that other towers were not as susceptible to weather conditions due to location and lack of a large basin. This issue of cooling towers and biocide and DO impact should be assessed on a case by case basis. Future work will include testing of L. pneumophila concentrations in cooling tower water with qPCR and culture techniques to asses viability and sensitivity factors.

\section{DATA AVAILABILITY STATEMENT}

All datasets generated for this study are included in the article/supplementary material.

\section{AUTHOR CONTRIBUTIONS}

All authors contributed equally to this manuscript in terms of sampling, testing, analysis, and authorship.

\section{FUNDING}

Work accomplished under Contract No. DE-AC09-08SR22470 with the U.S. Department of Energy.

\section{ACKNOWLEDGMENTS}

We thank Tommy Edwards, SRNL, for Technical Assistance. Software used: JMP Pro Version 11.2.1 SAS Institute Inc., Cary, NC, 2014.

in reverse osmosis desalination. Clean Water 2:2. doi: 10.1038/s41545-0180024-8

Allegra, A., Riffard, S., Leclerc, L., Girardot, F., Stauffert, M., Forest, V., et al. (2020). A valuable experimental setup to model exposure to Legionella's aerosols generated by shower-like systems. Water Res. 172:115496. doi: 10.1016/j.watres. 2020.115496

Alvarez, J., Domínguez, A., Sabrià, M., Ruiz, L., Torner, N., Cayla, J., et al. (2009). Impact of the Legionella urinary antigen test on epidemiological trends in community outbreaks of legionellosis in Catalonia, Spain. 1990-2004. Int. J. Infect. Dis. 13, e365-e370.

Atlas, R. M. (1999). Legionella: from environmental habitats to disease pathology, detection and control. Environ. Microbiol. 1, 283-293. doi: 10.1046/j.14622920.1999.00046.x 
Bentham, R. H. (2000). Routine sampling and the control of Legionella spp. in cooling tower water systems. Curr. Microbiol. 41, 271-275. doi: 10.1007/ s002840010133

Bentham, R. H., and Broadbent, C. R. (1993). A model for autumn outbreaks of Legionnaires' disease associated with cooling towers, linked to system operation and size. Epidemiol. Infect. 111, 287-295. doi: 10.1017/s0950268800056995

Berendt, R. F. (1980). Survival of Legionella pneumophila in aerosols: effect of relative humidity. J. Infect. Dis. 141:689. doi: 10.1093/infdis/141.5.689

Berk, S. G., Gunderson, J. H., Newsome, A. L., Farone, A. L., Hayes, B. J., and Redding, K. S. (2006). Occurrence of infected amoebae in cooling towers compared with natural aquatic environments: implications for emerging pathogens. Environ. Sci. Technol. 40, 7440-7444. doi: 10.1021/es0604257

Berk, S. G., Ting, R. S., Turner, G. W., and Ashburn, R. J. (1998). Production of respirable vesicles containing live Legionella pneumophila cells by two Acanthamoeba spp. Appl. Environ. Microbiol. 64, 279-286. doi: 10.1128/aem. 64.1.279-286.1998

Bibb, W. F., Arnos, P. M., Thacker, L., and McKinney, R. M. (1984). Detection of Soluble Legionella pneumophila antigens in serum and urine specimens by enzyme-linked immunosorbent assay with monoclonal and polyclonal antibodies. J. Clin. Microbiol. 20, 478-482. doi: 10.1128/jcm.20.3.478-482.1984

Bollin, G. E., Plouffe, J. F., Para, M. F., and Hackman, B. (1985). Aerosols containing Legionella pneumophila generated by shower heads and hot-water faucets. Appl. Environ. Microbiol. 50, 1128-1131. doi: 10.1128/aem.50.5.1128-1131. 1985

Brown, C. M., Nuorti, P. J., Breiman, R. F., Hathcock, A. L., Fields, B. S., and Lipman, H. B. (1999). A community outbreak of Legionnaires' disease linked to hospital cooling towers: an epidemiological method to calculate dose of exposure. Int. J. Epidemiol. 28, 353-359. doi: 10.1093/ije/28.2.353

Buchbinder, S., Trebesius, K., and Heesemann, J. (2002). Evaluation and detection of Legionella spp. in water samples by fluorescence in situ hybridization, PCR amplification and bacterial culture. Intern. J. Med. Microbiol. 292, 241-245. doi: 10.1078/1438-4221-00213

Carducci, A., Verani, M., and Battistini, R. (2010). Legionella in industrial cooling towers: monitoring and control strategies. Lett. Appl. Microbiol. 50, 24-29. doi: 10.1111/j.1472-765x.2009.02750.x

Chang, B., Sugiyama, K., Taguri, T., Amemura-Maekawa, J., Kura, F., and Watanabe, H. (2009). Specific detection of viable Legionella cells by combined use of photoactivated ethidium monoazide and PCR/Real-time PCR. Appl. Environ. Microbiol. 75, 147-153. doi: 10.1128/aem.00604-08

Cooper, A. J., Barnes, H. R., and Meyers, E. R. (2004). Assessing risk of Legionella. ASHRAE J. 46, 22-28.

Costa, J., Tiago, I., da Costa, M. S., and Verissimo, A. (2005). Presence and persistence of Legionella spp. in groundwater. Appl. Environ. Microbiol. 71, 663-671. doi: 10.1128/aem.71.2.663-671.2005

Dalebroux, Z. D., Edwards, R. L., and Swanson, M. S. (2009). SpoT governs Legionella pneumophila differentiation in host macrophages. Mol. Microbiol. 71, 640-658.

De Giglio, O., Fasano, F., Diella, G., Lopuzzo M., Napoli C., Apollonio, F., et al. (2019). Legionella and legionellosis in touristic-recreational facilities: influence of climate factors and geostatistical analysis in Southern Italy (2001-2017). Environ. Res. 178:108721. doi: 10.1016/j.envres.2019.108721

Declerck, P. (2010). Biofilms: the environmental playground of Legionella pneumophila. Environ. Microbiol. 12, 557-566. doi: 10.1111/j.1462-2920.2009. 02025.x

Dondero, T. J. Jr., Rendtorff, R. C., Mallison, G. F., Weeks, R. M., and Levy, J. S. (1980). An outbreak of Legionnaires' disease associated with a contaminated air-conditioning cooling tower. N. Engl. J. Med. 302, 365-370. doi: 10.1056/ nejm 198002143020703

Dunn, C. E., Rowlingson, B., Bhopal, R. S., and Diggle, P. (2013). Meteorological conditions and incidence of Legionnaires' disease in Glasgow, Scotland: application of statistical modelling. Epidemiol. Infect. 141, 687-696. doi: 10. 1017/s095026881200101x

Edagawa, A., Kimura, A., Doil, H., Tanaka, H., Tomioka, K., Sakabe, K., et al. (2009). Detection of culturable and nonculturable Legionella species from hot water systems of public buildings in Japan. J. Appl. Microbiol. 105, 2104-2114. doi: 10.1111/j.1365-2672.2008.03932.x

Edelstein, P. H., and Edelstein, M. A. C. (1989). Evaluation of the MerifluorLegionella immunofluorescent reagent for identifying and detecting 21
Legionella species. J. Clin. Microbiol. 27, 2455-2458. doi: 10.1128/jcm.27.11. 2455-2458.1989

Emmerson, A. M. (2001). Emerging waterborne infections in health-care settings. Emerg. Infect. Dis. 7, 272-276. doi: 10.3201/eid0702.010225

Fields, B. S., Benson, R., and Besser, R. E. (2002). Legionella and Legionnaires' disease: 25 years of investigation. Clin. Microbiol. Rev. 15, 506-526. doi: 10. $1128 / \mathrm{cmr} .15 .3 .506-526.2002$

Fliermans, C. B. (1985). "Ecological niche of Legionella pneumophila," in Critical Reviews of Microbiology, ed. R. S. Katz, (Boca Raton, FL: Springer), 75-116. doi: 10.1201/9781351073981-6

Han, X. Y. (2019). Solar and climate effects explain the wide variation in Legionellosis incidence rates in the united states. Appl. Environ. Microbiol. 85:e01776-19.

Hussong, D., Colwell, R. R., O’Brien, M., Weiss, E., Pearson, A. D., Weiner, R. M., et al. (1987). Viable Legionella pneumophila not detectable by culture on agar media. Biotechnology 5, 947-950. doi: 10.1038/nbt0987-947

Ishimatsu, S., Miyamoto, H., Hori, H., Tanaka, I., and Yoshida, S. I. (2001). Sampling and detection of Legionella pneumophila aerosols generated from an industrial cooling tower. Ann. Occup. Hyg. 54, 421-427. doi: 10.1016/s00034878(00)00068-5

Katsiaflaka, A., Pournaras, S., Kristo, I., Mouchtouri, V. A., Kyritsi, M., Velonakis, E., et al. (2016). Epidemiological investigation of Legionella pneumophila serogroup 2 to 14 isolates from water samples by amplified fragment length polymorphism and sequence-based typing and detection of virulence traits. Appl. Environ. Microbiol. 82, 6102-6108. doi: 10.1128/aem.01672-16

Kim, B. R., Anderson, J. E., Mueller, S. A., Gaines, W. A., and Kendall, A. M. (2002). Literature review-efficacy of various disinfectants against Legionella in water systems. Water Res. 36, 4433-4444. doi: 10.1016/s0043-1354(02)00188-4

Kusnetsov, J. M., Tulkki, A. I., Ahonen, H. E., and Martikainen, P. J. (1997). Efficacy of three prevention strategies against Legionella in cooling water systems. J. Appl. Microbiol. 82, 763-768. doi: 10.1046/j.1365-2672.1997.00151.x

Laganà, P., Moscato, U., Poscia, A., La Milia, D., Boccia, S., Avventuroso, E., et al. (2015). The distribution of Legionella pneumophila in a hospital water system. Ann. Agric. Environ. Med. 22, 655-660.

Lau, H. Y., and Ashbolt, N. J. (2009). The role of biofilms and protozoa in Legionella pathogenesis: implications for drinking water. J. Appl. Microbiol. 107, 368-378. doi: 10.1111/j.1365-2672.2009.04208.x

Lawrence, C., Reyrolle, S. D., Forey, F., Decludt, B. N., Goulvestre, P. M., Etienne, J., et al. (1999). Single clonal origin of a high proportion of Legionella pneumophila serogroup 1 isolates from patients and the environment in the Area of Paris, France, over a 10-year period. J. Clin. Microbiol. 37, 2652-2655. doi: 10.1128/ jcm.37.8.2652-2655.1999

Leskinen, S. D., Kearns, E. A., Jones, W. L., Miller, R. S., Bevitas, C. R., Kingsley, M. T., et al. (2012). Automated dead-end ultrafiltration of large volume water samples to enable detection of low-level targets and reduce sample variability. J. Appl. Microbiol. 113, 351-360. doi: 10.1111/j.1365-2672.2012.05 345. $\mathrm{x}$

Lettinga, K. D., Verbon, A., Weverling, G. J., Schellekens, F. P., Den Boer, J. W., and Prins, J. (2002). Legionnaires' disease at a dutch flower show: prognostic factors and impact of therapy. Emerg. Infect. Dis. 8, 1448-1454. doi: 10.3201/eid0812. 020035

Mallison, G. F. (1980). Legionellosis: environmental aspects. Ann. NY. Acad. Sci. 353, 67-70. doi: 10.1111/j.1749-6632.1980.tb18907.x

Marchesi, I., Ferranti, G., Mansi, A., Marcelloni, A. M., Proietto, A. R., Saini, N., et al. (2016). Control of Legionella contamination and risk of corrosion in hospital water networks following various disinfection procedures. Appl. Environ. Microbiol. 82, 2959-2965. doi: 10.1128/AEM.03873-15

Marston, B. J., Lipman, H. B., and Breiman, R. F. (1994). Surveillance for Legionnaires' disease. Risk factors for morbidity and mortality. Arch. Intern. Med. 154, 2417-2422. doi: 10.1001/archinte.154.21. 2417

Matsui, M., Fuji, S.-I., Shiroiwa, R., Amemura-Maekawa, J., Chang, B., Kura, F., et al. (2010). Isolation of Legionella rubrilucens from a pneumonia patient coinfected with Legionella pneumophila. J. Med. Microbiol. 59, 1242-1246. doi: 10.1099/jmm.0.016089-0

McNealy, T., Newsome, A. L., Johnson, R. A., and Berk, S. G. (2002). "Impact of Amoebae, Bacteria, and Tetrahymena on Legionella pneumophila multiplication and distribution in an aquatic environment," in Legionella, eds 
Y. Marre, C. AbuKwaik, N. Bartlett, B. Cianciotto, S. Fields, M. Frosch, et al. (Washington, DC: ASM Press).

Me'rault, N., Rusniok, C., Jarraud, S., Gomez-Valero, L., Cazalet, C., and Marin, M. (2011). Specific Real-Time PCR for simultaneous detection and identification of Legionella pneumophila Serogroup 1 in water and clinical samples. Appl. Environ. Microbiol. 77, 1708-1717.

Miller, R. D., and Koebel, D. A. (2005). Legionella prevalence in cooling towers: association with specific biocide treatments. ASHRAE Trans. 112, 700-708

Miyashita, N., Higa, F., Aoki, Y., Kikuchi, T., Seki, M., and Tateda, K. (2020). Distribution of Legionella species and serogroups in patients with cultureconfirmed Legionella pneumonia. J. Infect. Chemother. 26, 411-417. doi: 10. 1016/j.jiac.2019.12.016

Nguyen, T. M. N., Ilef, D., Jarraud, S., Rouil, L., Campese, C., Che, D., et al. (2006). A community-wide outbreak of legionnaires disease linked to industrial cooling towers-how far can contaminated aerosols spread? J. Infect. Dis. 193, 102-111. doi: $10.1086 / 498575$

Orrison, L. H., Cherry, W. B., Fliermans, C. B., and Pope, D. H. (1983). Susceptibility of algae and Legionella pneumophila to cooling tower biocides. Appl. Environ. Microbiol. 45, 1254-1260. doi: 10.1128/aem.45.4.1254-1260. 1983

Paniagua, A. T., Paranjape, K., Hu, M., Bédard, E., and Faucher, S. P. (2020). Impact of temperature on Legionella pneumophila, its protozoan host cells, and the microbial diversity of the biolm community of a pilot cooling tower. Sci. Tot. Environ. 7:136131. doi: 10.1016/j.scitotenv.2019.136131

Paranjape, K., Bédard, E., Whyte, L. G., Ronholm, J., Prevost, M., and Faucher, S. P. (2020). Presence of Legionella spp. in cooling towers: the role of microbial diversity, Pseudomonas, and continuous chlorine application. Water Res. 169:115252. doi: 10.1016/j.watres.2019.115252

Parthuisot, N., West, N. J., Lebaron, P., and Baudart, J. (2010). High diversity and abundance of Legionella spp. in a 1 pristine river and the impact of seasonal and anthropogenic effects. Appl. Environ. Microbiol. 76, 8201-8210. doi: 10.1128/aem.00188-10

Pierre, D. M., Baron, J., Yu, V. L., and Stout, J. E. (2017). Diagnostic testing for Legionnaires' disease. Ann. Clin. Microbiol. Antimicrob. 16:59. doi: 10.1186/ s12941-017-0229-6

Pinel, I. S. M., Moed, D. H., Vrouwenvelder, J. S., and van Loosdrecht, M. C. M. (2020). Bacterial community dynamics and disinfection impact in cooling water systems. Wat. Res. 172:115505. doi: 10.1016/j.watres.2020.115505

Sakamoto, R., Ohno, A., Nakahara, T., Satomura, K., Iwanaga, S., Kouyama, Y., et al. (2009). Legionella pneumophila in rainwater on roads. Emerg. Infect. Dis 15, 1295-1297.

Sanchez, I., Garcia-Nuñez, M., Ragull, S., Sopena, N., Pedro-Botet, M. L., and Esteve, M. (2008). Genotypic variability and persistence of Legionella pneumophila PFGE patterns in 34 cooling towers from two different areas. Environ. Microbiol. 10, 395-399. doi: 10.1111/j.1462-2920.2007.01460.x

Shelton, B. G., Flanders, W. D., and Morris, G. (1994). Legionnaires' disease outbreaks and cooling towers with amplified Legionella concentrations. Curr. Microbiol. 28, 359-363. doi: 10.1007/bf01570202

Shelton, B. G., Kerbel, W., Witherell, L., and Millar, J. D. (2000). Review of Legionnaires' disease. AIHA J. 61, 738-742.
Simmering, J. E., Polgreen, L. A., Hornick, D. B., Sewell, D. K., and Polgreen, P. M. (2017). Weather-dependent risk for Legionnaires' disease, United States. Emerg. Infect. Dis. 23, 1843-1851. doi: 10.3201/eid2311.17 0137

Spiegelman, J., Pedutem, T., and Francisco, M. J. (2020). Legionnaires' disease cases at a large community hospital-common and underdiagnosed. Int. J. Environ. Res. Public Health 17:332. doi: 10.3390/ijerph17010332

Ulleryd, P., Hugosson, A., Allestam, G., Sverker, B., Berndt, E. B. C., and Ingrid, E. (2012). Legionnaires' disease from a cooling tower in a community outbreak in Lidköping, Sweden- epidemiological, environmental and microbiological investigation supported by meteorological modelling. BMC Infect. Dis. 12:313. doi: 10.1186/1471-2334-12-313

Villanueva, D., and Schepanski, K. (2019). Investigation of atmospheric conditions fostering the spreading of Legionnaires' disease in outbreaks related to cooling towers. Int. J. Biometeorol. 63, 1347-1356. doi: 10.1007/s00484-01901751-9

Wadowsky, R. M., Wolford, R., McNamara, A. M., and Yee, R. B. (1985). Effect of temperature, $\mathrm{pH}$, and oxygen level on the multiplication of naturally occurring Legionella pneumophila in potable water. Appl. Environ. Microbiol. 49, 11971205. doi: 10.1128/aem.49.5.1197-1205.1985

Ward, W., Boland, M., Nicolay, N., Murphy, H., McElhiney, J., Collins, C., et al. (2010). A cluster of Legionnaires' disease and associated pontiac fever morbidity in office workers, dublin, June-July 2008. J. Environ. Public Health 2010:463926. doi: 10.1155/2010/463926

Wellinghausen, N., Frost, C., and Marre, R. (2001). Detection of Legionellae in hospital water samples by quantitative real-time lightCycler PCR. Appl. Environ. Microbiol. 67, 3985-3993. doi: 10.1128/aem.67.9.3985-3993. 2001

Wery, N., Bru-Adan, V., Minervini, C., Delge'nes, J.-P., Garrelly, L., and Godon, J.-J. (2008). Dynamics of Legionella spp., and bacterial populations during the proliferation of L. pneumophila in a cooling tower facility. Appl. Environ. Microbiol. 74, 3030-3037. doi: 10.1128/aem.02760-07

Whiley, H., Keegan, A., Fallowfield, H., and Ross, K. (2014). Uncertainties associated with assessing the public health risk from Legionella. Front. Microbiol. 24:501. doi: 10.3389/fmicb.2014.00501

Zahran, S., McElmurry, S. P., Kilgore, P. E., Mushinski, D., Press, J., Love, N. G., et al. (2017). Assessment of the Legionnaires' disease outbreak in Flint, Michigan. Proc. Natl. Acad. Sci. U.S.A. 115, E1730E1739.

Conflict of Interest: The authors declare that the research was conducted in the absence of any commercial or financial relationships that could be construed as a potential conflict of interest.

Copyright (c) 2020 Brigmon, Turick, Knox and Burckhalter. This is an open-access article distributed under the terms of the Creative Commons Attribution License (CC BY). The use, distribution or reproduction in other forums is permitted, provided the original author(s) and the copyright owner(s) are credited and that the original publication in this journal is cited, in accordance with accepted academic practice. No use, distribution or reproduction is permitted which does not comply with these terms. 